\title{
ČASOPIS KAO AMBLEM POSLEDNJEG ČASA: MEĐUSOBNA USLOVLJENOST MOTIVA SMRTI I MOTIVA PERIODIČNE ŠTAMPE U PRIPOVETKAMA VLADANA DESNICE
}

\section{Stanislava Barać}

UDK: 821.163.42-32Desnica, V.:393

Izvorni znanstveni članak

Sažetak: U četiri pripovetke Vladana Desnice periodična štampa upotrebljena je kao motiv koji će amblematski potkrepiti opštiji motiv odnosno temu umiranja, smrti i ljudske prolaznosti. Desnica koristi niz raznolikih periodičnih žanrova (kalendar / almanah, kulturnopolitički časopis, esnafski polumesečnik, dnevne novine) kako bi umetnički konkretizovao metafizičku temu i filozofsku poruku koju preko nje prenosi. Cilj ovog rada je da ukaže na raznovrsnost načina na koje se navedeni motivi ugrađuju u narativnu i semantičku strukturu pripovedaka i na umetničku inovativnost i estetske efekte ovog pripovednog postupka. Takođe, cilj rada je da opiše kako dati motivi funkcionišu u okviru poetike Vladana Desnice. Oni, naime, učestvuju u oblikovanju semantičke opozicije selo - grad (suprotnost ruralnog i urbanog shvatanja vremena i prolaznosti ističe se pomoću motiva kalendara-stogodnjaka u pripoveci Životna staza Jandrije Kutlače), i u povlašćivanju teme smrti: u oblikovanju slike umiranja kao procesa (što se postiže uvođenjem imaginarnog Glasnika udruženja poštanskih službenika u pripovetku Oproštaj), u prikazivanju smrtnosti kao biološkog usuda (čemu služi Večernji list u pripoveci Zlatni rudnik) i u iskazivanju ideje ljudske prolaznosti preko prikazivanja nestalnosti i varljivosti društvene slave, bilo političke (što je postignuto preko motiva izmišljenog lista $\mathrm{No}$ va zora u pripoveci Konac dana), bilo umetničke (pomoću Večernjeg lista u Zlatnom rudniku).

Ključne reči: Vladan Desnica, pripovetke, poetika, periodična štampa, vreme, prolaznost, konkretno, univerzalno

Drvi put je zamisao o uzajamnosti motiva smrti i periodične štampe Vladan Desnica oblikovao već u svojoj prvoj pripoveci, Životna staza Jandrije Kutlače, objavljenoj 1935. godine u „sopstvenoj“ periodičnoj publikaciji, Magazinu Sjeverne Dalmacije, godišnjaku čiji je bio urednik. ${ }^{1}$ Trenutak u kome je Magazin osnovan (1934) pripada epohi u kojoj

1 O složenosti institucionalnih i ličnih odnosa iz kojih je nastao, a zbog kojih je potom ugašen ovaj almanah videti: Drago Roksandić, „Vladan Desnica i Magazin Sjeverne Dalmacije: književnik i (ne)moć tradicije“, Vladan Desnica i 
se čitalačka publika Kraljevine Jugoslavije intenzivno diferencirala zahvaljujući procesima društvene stratifikacije i (ograničene) modernizacije. To je rezultiralo stalnim pokretanjima novih i specijalizovanih periodičnih publikacija koje su izražavale programe i interesovanja najraznovrsnijih grupa i pokreta, kako onih sa istorijskim kontinuitetom, tako i potpuno novih društvenih činilaca. ${ }^{2}$ I sam Magazin je, dakle, proizvod datoga trenutka, a Vladan Desnica samosvesni i upućeni akter aktuelne medijske scene. Zato nije neobično što je ova važna činjenica Desničine intelektualne biografije, ali i porodične istorije, dobila svoj izraz, makar i amblematski, ${ }^{3}$ u fikcionalnom svetu njegovih pripovedaka.

Reč je, međutim, i o mnogo širem fenomenu: o globalnoj društvenoj sveprisutnosti periodične štampe u drugoj polovini 19. i prvoj polovini 20. veka. Ona se u evropskoj književnosti reflektuje ne samo na planu prikazane predmetnosti, u učestalosti odgovarajućih „periodičarskih“ "tema i motiva odnosno likova koji uređuju i štampaju časopise, već bitno utiče na samu prirodu pripovedanja. Valter Benjamin 1936. godine u danas čuvenom eseju Pripovedač. Razmatranja uz delo Nikolaja Ljeskova iznosi tezu da je medijska epoha, naročito nakon katastrofe Prvog svetskog rata, promenila ljudsko iskustvo (,iskustvo je pretrpelo pad u svojoj vrednosti“), kao i mogućnosti njegovog pripovednog prenošenja (,zanemelost“, „siromaštvo u saopštivom iskustvu“). Benjamin uočava da je

(...) s prodorom dominacije građanskog sveta, a među najvažnije instrumente te dominacije u poznom kapitalizmu spada štampa, na poprište izbio izvestan oblik saopštavanja koji, koliko god se davno začeo, nikad pre toga nije na presudan način uticao na epski oblik. ${ }^{4}$

Informacija, taj novi oblik saopštavanja, u suprotnosti je sa duhom priče i, po Benjaminovom uverenju, utiče na to da je sve manje „značajnih povesti“, usmenih i pisanih. Pripovetke Vladana Desnice, koje su nastajale upravo u to vreme, ${ }^{5}$ kao i delovi romana Proljeća Ivana Galeba, spadaju među one koje u epohi kraja priče čuvaju veru u saopštivost iskustva, iako je i problematizuju.

Split 1920. - 1945. Zbornik radova sa znanstvenog skupa Desničini susreti 2014. (ur. Drago Roksandić i Ivana Cvijović Javorina), Zagreb 2015., 181-234.

2 O tome sam pisala u članku „Implicitni čitalac Magazina Sjeverne Dalmacije: pokušaj rekonstrukcije“, Vladan Desnica i Split 1920. - 1945., 157-180.

3 Pojam amblem ovde se koristi u prenesenom značenju. Motivi periodične štampe se u Desničinim pripovetkama upotrebljavaju kao znak koji dodatno potcrtava situaciju i značenje koji su u pripoveci iskazani i drugim sredstvima. On je nalik znački na reveru junakovog kaputa, koja čitalačku pažnju dodatno fiksira na ideju koja je izrečena i celinom pripovetke, slično kao što Zdenko Škreb u odrednici „Amblem“ u Rečniku književnih termina objašnjava poreklo ovog pojma: „S druge strane, od kraja se 14. st. raširio običaj, najprije u Burgundiji i Francuskoj, a onda u Italiji, da građani patriciji i učenjaci na šeširu ili odijelu nose medalje s natpisima koje su se zvale imprese. Taj duh primitivne simbolike 16. st. našao je svoju kodifikaciju u djelu Alciatusa; u njemu se svaki amblem sastoji od tri dijela: slike, natpisa (inscriptio) koji joj tumači simboličko značenje, i teksta ispod nje (subscriptio), u vezi sa slikom, većinom u stihu, ali i u prozi, uzeta najčešće iz antikne književnosti. Npr. slika prikazuje kako kiša pada na biljke, a inscriptio tumači da božji blagoslov donosi bogatstvo; pas požudno gleda kako lav razdire plijen, a inscriptio tumači da je to želja bez nade da se ispuni - tekst ispod slike primjenjuje se na baštinika koji požudno očekuje smrt bogata rođaka, u duhu se naslađuje ali usta mu ostaju suha.“ Zdenko ŠKREB, „Amblem“, Rečnik književnih termina, Beograd 1992. 20.

4 Валтер БенјАмин, „Приповедач. Разматрања уз дело Николаја Вескова“, Искуство и сиромаштво, БеограА 2016., 68 .

5 Cela jedna zbirka priča pripremljena za beogradskog izdavača Gecu Kona izgubljena je u Drugom svetskom ratu, zbog čega su one većinom rekonstruisane i objavljene neposredno posle rata. 
Na pomenutom je Benjaminovom eseju Vladimir Biti zasnovao izvrsnu analizu Desničinog Proljeća Ivana Galeba, izloženu 1994. godine u nacrtu, a objavljenu u proširenoj verziji 2004. Ta je analiza u isto vreme i svojevrsno preispitivanje teorija pripovedanja u 20. veku. Bitijeva studija, između ostalog, jasno pokazuje koliko Benjaminova razmatranja i Desničino romaneskno pripovedanje jedno drugo uzajamno objašnjavaju. Biti podrazumeva da Benjaminova razmatranja prethode Desničinoj pripovedačkoj poetici, pa na početku svoje studije kaže:

Kada je ustvrdio kako je „smrt sankcija svemu o čemu pripovjedač može izvjestiti“ te kako je pripovjedač „od smrti posudio autoritet“, Walter Benjamin kao da je anticipirao pojavu Desničina pripovjedača Ivana Galeba. ${ }^{6}$

Reč je, međutim, o naporednim epohalnim pojavama, koje se kao takve ukazuju kada se u obzir uzmu i Desničine pripovetke. $\mathrm{Na}$ istom je Benjaminovom eseju, pozivajući se i na Bitija, analizu Proljeća Ivana Galeba u velikoj meri zasnovao i Milomir Gavrilović (2017).? Autoru je upravo Benjaminov pojam iskustva pomogao da preosmisli pojam enciklopedijskog modela proze, u koji je onda mogao da uključi i Desničin roman. U svakom slučaju, Benjaminove se postavke sistematski primenjuju na Desničin roman, dok se njegove pripovetke u tom kontekstu zapostavljaju, iako je nemački teoretičar u ovom uticajnom eseju govorio upravo o pripovetkama, smatrajući roman, uz periodičnu štampu, jednim od neprijatelja "klasičnog“ načina pripovedanja.

Časopisni motivi pojavljuju se u većem broju Desničinih pripovedaka, a u četiri pripovetke periodična štampa upotrebljena je specifičnije - kao motiv koji će amblematski potkrepiti opštiji motiv odnosno temu umiranja, smrti i ljudske prolaznosti. Desnica je iskoristio niz raznolikih periodičnih žanrova (kalendar / almanah odnosno godišnjak, kulturno-politički časopis, esnafski polumesečnik i dnevne novine) kako bi umetnički konkretizovao metafizičku temu i filozofsku poruku koju preko nje prenosi. Ovi motivi-amblemi učestvuju, naime, u oblikovanju semantičke opozicije selo - grad (i odgovarajućih koncepcija vremena), a zatim i u povlašćivanju teme smrti: kroz oblikovanje slike umiranja kao procesa, kroz prikazivanje smrtnosti kao biološkog usuda i kroz iskazivanje ideje ljudske prolaznosti preko prikazivanja nestalnosti i varljivosti društvene slave. Specifična umetnička vrednost Desničine proze ne leži, međutim, samo u inovativnom prikazivanju aspekata smrtnosti i iskazivanju ideja u tome domenu, već i u proizvođenju određenog estetskog / čulnog doživljaja. Pomoću datih slika i semantema, u sveukupnom dejstvu pripovedačkih postupaka, u čitalačkom se doživljaju, naime, ostvaruju i efekti samog proticanja vremena, odnosno samog osećaja prolaznosti. ${ }^{8}$

6 Vladimir Biтi, „Mama-Yumba i Mumbo Jumbo: Proljeća Ivana Galeba Vladana Desnice“, Doba svjedočenja, Zagreb 2005., 135.

7 Videti: Milomir Gavrilović, „Odlike enciklopedijskog modela proze u Proljećima Ivana Galeba Vladana Desnice i Peščaniku Danila Kiša“, Hrvatsko-srpski / srpsko-hrvatski interkulturalizam danas. Zbornik radova s mecunarodnoga znanstvenog skupa Desničini susreti 2016. (ur. Drago Roksandić), Zagreb 2017., 236-248.

8 Izbor izraza efekat u kontekstu pitanja umetničke vrednosti motivisan je i jednim Desničinim objašnjenjem iz 1958. godine: „U našoj tekućoj kritici i u razgovorima naše književne svakidašnjice kao da se daleko više pretresa o tehničko-literarnim načinima i postupcima nego o efektu koji je tim načinima i tim postupcima postignut, i kao da se estetska vrijednost traži i pronalazi ne u ostvarenim rezultatima već u upotrebljenim sredstvima." Vladan DesNiCA, „Ličnost i prosede“, Eseji, kritike, pogledi (= Sabrana djela Vladana Desnice, knj. IV), Zagreb 1975., 113. 
Već, dakle, u svojoj prvoj pripoveci, Životna staza Jandrije Kutlače, Desnica višestruko upotrebljava motive periodične štampe. Na osnovnom nivou, ovi su motivi u funkciji izgradnje likova. Kao opštiji motiv, periodika je prisutna u karakterizaciji lika Leopolda, starijeg sina glavnog junaka. To „dijete ni da čuje za kadetsku školu, nego udarilo u politiku, u novine, u pokret. - Bog bi ga znao na šta je okrenuo! - jadao se Jandrija. - Biću veli novinar, te ovo, te ono, te prosvjećivati i urazumljivati narod. “9 Konkretniji motiv dnevnih novina, zatim, Desnica je upotrebio kao znak političkih transformacija i stranačko-političke strasti lika. Glavni junak Jandrija Kutlača, kada se „obrete u svojoj narodnoj državi i pitomome primorskome gradu“, ${ }^{10}$ navikne „na jedne novine, pa ih uvijek kupuje i čita. Čita ih od az do ižice, u svako doba dana i na svakom mjestu: hoda polako i čita, zastajkiva i sriče. Naročito pred izbore jako se zanima. "“11 Nekadašnji verni službenik Austrougarske monarhije, štaviše njen vojnik, Jandrija Kutlača se, kao oličenje konformizma i oportunizma, lako saživljava sa novom državom („svojom narodnom“), nastalom na ruševinama prethodne, i posebno se vezuje za jedan list. Čitaoce Magazina Sjeverne Dalmacije, prve čitaoce ove pripovetke, asocijacije su svakako vodile ka vantekstovnoj realnosti i dnevnim novinama Politika. Iako je za temu ovoga rada od mnogo veće relevantnosti upotreba drugog „periodičkog“ motiva, kalendara-stogodnjaka, nužno je ipak zadržati se na trenutak na slici starca nestrpljivog da stigne do kuće ili kafane kako bi pročitao dnevne vesti. U karakterizaciji junaka - kojeg postupno, do kraja pripovetke, Desnica u mnogo čemu određuje kao negativnog (konzervatizam ${ }^{12}$ i militarizam) - istovremeno postoje elementi koji ga čine oličenjem solarnog principa i pobede života nad smrću. Naime, upravo je, pri kraju pripovetke, uronjenost $\mathrm{u}$ (svako)dnevno zbivanje, pa u tom smislu efemerno, prolazno, $\mathrm{u}$ isto vreme znak junakovog pristajanja na (novi) život, i svoju (prolaznu) ulogu u njemu. Zato na samom kraju pripovetke stoji groteskna slika glavnog junaka kako, obasjan suncem, zadovoljno sedi $u$ sopstvenom budućem grobu („,kad je poslije rada sjedio na suncu u grobu“). ${ }^{13}$

Upravo ta slika pomirenosti sa životom / smrću, ali i sjedinjenosti sa zemljom, vraća čitaoca na početak pripovetke, gde je uveden motiv kalendara-stogodnjaka kako bi se izgradila karakterološka opozicija između starijeg brata Petra i mlađeg Jandrije, čijem će se liku, potom, priča isključivo posvetiti. Tu se, posebno u izmenjenoj drugoj verziji, u zbirci Olupine na suncu, nalazi jedan iskaz važan za ovu temu. U Magazinu Sjeverne Dalmacije u uvodnom delu pripovetke stoji:

\footnotetext{
9 ВАадан АЕсницА, „Животна стаза Јандрије Кутлаче (скица за роман)“, Магазин Сјеверне Аалмащије, 2/1935., 161.

10 Isto, 169. U drugoj verziji pripovetke država više ne nosi epitet narodne, a primorski grad je imenovan: „A kad sve to minu, on se obrete u novoj državi, u pitomome primorskome gradu, na toplom suncu - preselio je ono nešto kućnih stvari u Split i tu se nastanio“. Vladan Desnica, „Životna staza Jandrije Kutlače“, Pripovijetke (= Sabrana djela Vladana Desnice, knj. III), Zagreb 1974., 80.

11 В. АЕсницА, „Животна стаза Јандрије Кутмаче“, 170.

12 Desnica jasno aludira na Jandrijine političke simpatije prema Nikoli Pašiću: „Ali on je ipak znao za koga će se opredijeliti. (...) Nije njemu zaludu Stari dao pensiju po novom zakonu. (...) Naslutio Jandrija u Starome onaj red i starješinstvo, ono državno načelo - sve kao ono carsko što je bilo." Isto, 170.

13 Isto, 172.
} 
Petar, kao stariji, uze upravljati kućom. To je bio ozbiljan i uravnotežen težak, pravi zemljoradnik; nikad nije ni pomislio na drugo podneblje ili na drugačiji život; bio je zadovoljan da jedan dan sliči drugom i jedna godina drugoj. Izmjenu, prilično pravilnu, rodnih godina sa gladnim, ljutih zima i kišljivih proljeća sa sušnim ljetima i lijepim jesenima primao je gotovo kao jednu kalendarsku određenost i ona je zadovoljavala potpuno svu potrebu njegove duše za promjenom. ${ }^{14}$

U drugoj i proširenoj verziji iste pripovetke, u zbirci Olupine na suncu (1952), Desnica je u dati deo uneo izmene koje su išle upravo u smeru eksplicitnog povezivanja ruralnog, preciznije ratarskog načina života i samih kalendarskih publikacija, odnosno razotkrivale da je pod „kalendarskom određenošću“ Desnica doslovno podrazumevao i kalendarsku periodiku:

Petar se po očevoj smrti naglo uozbilji; uzme odmah upravljati kućom i odnositi se prema Jandriji s očinskom vlašću. Bio je to šutljiv i uravnotežen seljak, pravi ratar. Bio je zadovoljan da jedan dan sliči drugome i jedna godina drugoj. Izmjenu, prilično pravilnu, osrednjih godina sa gladnim, ljutih zima i kišljivih proljeća sa sušnim ljetima i vedrim jesenima, što se redalo tačno onako kako je kazano u kalendaru-stogodnjaku, primao je gotovo kao neku kalendarsku određenost, i to očekivano i unaprijed znano smjenjivanje zadovoljavalo je potpuno njegovu potrebu za promjenom. ${ }^{15}$

Da bi se potpunije razumela suprotna priroda Jandrije Kutlače, kojem će sva dalja priča biti posvećena, potrebno je podsetiti šta je to „kazano“ u kalendaru-stogodnjaku. „Izvornim“ čitaocima pripovetke, kao čitaocima Magazina Sjeverne Dalmacije, bila je poznata pa i intimno bliska kalendarska i almanaška kultura, i to kako na srpskom i hrvatskom tako i na italijanskom jeziku, dok je već za dobar deo publike koja ju je čitala unutar zbirke, nakon Drugog svetskog rata, to mogla biti potpuno nepoznata pojava. Ljubitelj prosveštenija. Srbsko-dalmatinski almanah (1836-1873), ${ }^{16}$ izabrani preteča Desničinog godišnjaka, sadržao je, naime, na početnim stranicama tada obavezni kalendarski segment. ${ }^{17}$ Taj se segment sastojao iz „letočislenija“, pashalije, (crkvenog) kalendara, prikaza mesečevih mena po mesecima, astrološkog predviđanja za datu godinu, rodoslova vladarske (u ovom slučaju austrijske) porodice i popis „funkcionera“ srpske pravoslavne crkve. U odeljku s astrološkim predviđanjima nalaze se, samo u ekstenzivnijem vidu i vezani za konkretnu godinu, upravo onakvi opisi godišnjih doba kakve daje i Desničin pripovedač. Tako, na primer, 1836. godinom carstvuje planeta Venus Danica - „imamo se nadati jakoj i držećoj zimi“, „biće proleće dovoljno vlažno, ali i suviše vetrovito“, „leto mnogo zapare i danju i noću obećava“, a jesen će biti „više vlažna nego suva, i zato teško ćemo postolna vina imati“ 18

14 Isto, 155.

15 V. Desnica, „Životna staza Jandrije Kutlače“, Pripovijetke, 59. Kurziv S. B. Oba su ova citata prisutna u pomenutom radu „Implicitni čitalac Magazina Sjeverne Dalmacije: pokušaj rekonstrukcije“, ali se ovde razmatraju u kontekstu drugog problema, pa ih je nužno ponovo i navesti.

16 Od 1838. Srbsko-dalmatinski magazin.

17 Kalendarski deo postojao je samo u prva dva godišta, a posle ga više nema. Upravo ovaj godišnjak pokazuje kako se odvijao prelaz od izvornih almanaha (kalendara zabavnika) ka „čistim“ almanasima tj. magazinima (časopisima), odnosno ilustruje kako su se na periferiji Habzburške monarhije u 19. veku odvijali procesi urbanizacije, scijentizacije i emancipacije - kao deo procesa modernizacije.

18 „Звеъздочетное Предувъщаніе на мьто Хрїстово 1836.“, АЮБИТЕАБ ПРОСВБШТЕНІЯ. СРБСКОАААМАТИНСКІЙ ААМАНАХЬ ЗА АБТО 1836., 21-22. 


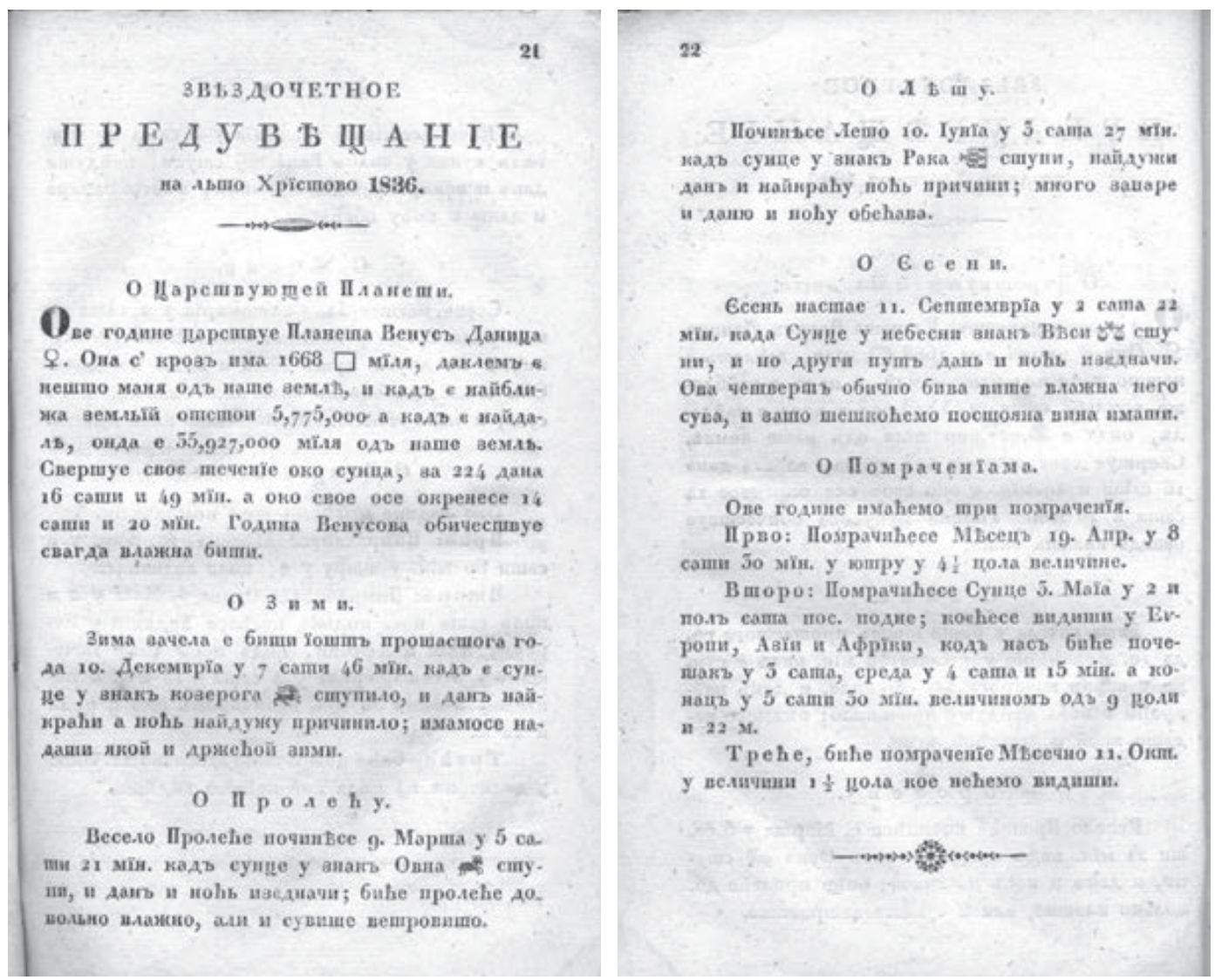

Sl. 1. Astrološka predviđanja za 1836. godinu u Srbsko-dalmatinskom almanahu

Takvi opisi, koji su se, uz varijacije, ponavljali iz godine u godinu, podrazumevali su cikličnu koncepciju vremena koja, dalje, podrazumeva i nekonfliktni odnos prema smrti. Čitaoci odnosno zemljoradnici prihvatali su ova astrološka predviđanja kao datost, i u odnosu na njih se upravljali. U pripoveci je takvoj koncepciji neposredno suprotstavljena koncepcija progresivnog pravolinijskog vremena tako što pripovedač odmah prelazi na opis drugog brata:

Jandrija je bio drukčiji. Nemirne ćudi i žive mašte, žustriji, spretniji, osjećao je u sebi pomalo puste porive i želju za značajnijim doživljajima. Nikad nije kovao dugoročne planove kao što čine ljudi koji računaju da će ostati dovijeka ondje gdje su se rodili. U njemu je želja za „širokim svijetom“ bila jaka još u doba kad o tom svijetu nije mogao da ima nikakvih određenih predstava. U tome kraju nije rijedak kod ljudi taj poriv. Odatle se, kao iz rasadnika, jači i otporniji primjerci presađuju u druge krajeve i novače u druge društvene redove; slabiji ostaju tu da rode spretnije i izdržljivije od sebe. ${ }^{19}$

Međutim, kao što je rečeno, Desnica ne ostaje na oblikovanju pojednostavljene opozicije, već glavnog junaka, nosioca principa linearne „progresivnosti“, na kraju postavlja u pozici- 
ju „pravog ratara“, koji prihvata princip cikličnog. Iz Jandrijine perspektive pripovedač, na kraju životne staze / priče, saopštava:

Ponekad mu se činilo kao da je u životu imao zadaću da iz postojbine u sebi iznese nešto dragocjenije i od sebe samoga i da to nešto njemu samome neznanim i nepronicavim stazama ovdje prenese i staloži. Tek sada, u starosti, osjetio je po prvi put potrebu da se stani i da pusti žile u tlo. Pa, i u toj brizi oko gradnje groba progovorila je njegova polusvijesna želja da svoje potomstvo veže za ovaj kutić zemnog šara i da ga u neku ruku učini nepokretljivim. ${ }^{20}$

Dva lika, koja oličavaju dve suprotstavljene koncepcije vremena, pa tako i smrti, na kraju su pomirena. Čitaoci iz ovakvog pripovedanja ne mogu da izvedu jed(nostr)an pripovedački odnosno autorski epistemološki i aksiološki stav, već je, kao što je ranije detektovano u analizi Desničinog Proljeća Ivana Galeba, reč o poziciji gnoseološkog relativizma ili integralizma, odnosno ambivalencije. Davor Dukić i Goranka Šutalo, usvajajući postavku Dragana Jeremića „o integralizmu kao Galebovoj (kod njega i Desničinoj) viziji života“, dalje preciziraju da „tu dubinsku semantičku potku Proljeća možemo na najapstraktnijoj razini označiti kao binarizam, a konkretnije kao dvojstvo kontradiktornih pojmova / pojava / načela“. Autori ističu da „dijalektika te kontradiktornosti ne pretpostavlja uzajamno isključivanje ili nadilaženje nekom trećom dimenzijom već upravo mirnu koegzistenciju suprotstavljenih polova“. ${ }^{21}$

O ovoj se karakteristici Desničine pripovedačke poetike raspravljalo najviše povodom romana Proljeća Ivana Galeba (1957), ali je vrlo važno istorizovati je i istaći da je upadljiva već u prvom pripovedačkom Desničinom delu (uostalom, Desnica je i roman počeo da piše u isto vreme). Takav integralizam ili ambivalenciju moguće je tumačiti kao odliku same figure pripovedača. Bar tako je u tom trenutku u svojoj književnoj odnosno teorijskoj imaginaciji vide Vladan Desnica i Valter Benjamin. Naime, figure i vrednosne perspektive ratara-sedeoca i nomada-lutalice se u pripovednoj instanci Desničine prve pripovetke objedinjuju, integralizuju, baš onako kao što Benjamin u eseju Pripovedač slikovito predstavlja velike pripovedače:

Iskustvo koje teče od usta do usta izvor je iz kojeg su crpli svi pripovedači. A među onima koji su priče zapisivali, veliki su oni čiji se zapis ponajmanje razlikuje od govora mnogih bezimenih usmenih pripovedača. Uostalom, među ovim poslednjim postoje dve grupe koje se uzajamno višestruko prožimaju. Sam pripovedačev lik poprima svoju punu telesnost samo za onoga ko ima predstavu o obe grupe. „Ko je putovao, ima šta da priča“, kaže narod i zamišlja pripovedača kao nekog ko dolazi iz daleka. Ali, ne manje rado slušamo i onog koji je, časno se prehranjujući, ostao u zemlji i poznaje njene priče i legende. Ako bismo obe te grupe hteli da predstavimo posredstvom njihovih arhaičnih zastupnika, onda je jedna oličena u sedelačkom zemljoradniku, a druga u trgovačkom pomorcu. ${ }^{22}$

Odnosno, kako Vladimir Biti sažima i parafrazira ovaj Benjaminov stav:

20 Isto, 172.

21 Davor Dukić - Goranka Šutalo, „Todesenthebung aus dem Sterbzimmer: koncepti ideologije i vlasti u recepciji Desničinih Proljeća Ivana Galeba“, Desničini susreti 2010. Zbornik radova (ur. Drago Roksandić i Ivana Cvijović Javorina), Zagreb 2011., 71-72.

22 В. БенјАмин, „Приповедач. Разматрања уз дело Николаја Һескова“, 61-62. 
Pripovjedač se tako prikazuje kao sjeditelj koji je za sobom ostavio nomadska lutanja, ratar $s$ nemirnom prošlošću pomorca, šegrt koji se okućio kao obrtnički gazda ne bi li osmislio svoje dugogodišnje potucanje. ${ }^{23}$

Koliko je Desničina pripovedačka (samo)svest proizlazila iz srodnih - ali i neposrednijih - izvora, kao i Benjaminova teorija pripovedanja, pokazuje njegov članak Juraj Carić - pisac mora (1954). Nazivajući Carića „pomorskim piscem“ i opisujući ovog moreplovca koji je postao pisac, Desnica otkriva jedan od živih primera kakvi su poslužili i Benjaminu u uobličenju teorije epskih oblika. Kod Carića Desnica izdvaja upravo neposrednost u prenošenju iskustva, kao i isprepletenost estetičkog i praktičkog:

Razumljivo, živeći i radeći u doba kad je širim redovima naše čitalačke publike pojam „knjige“ u svom punom dostojanstvu, zvučao još dosta unitarno, i kad duboko strahopočitanje prema tom pojmu nije ostavljalo mnogo mjesta preokupaciji za odveć strogim i teoretskim lučenjem takozvane „lijepe knjige“ od poučne i korisne, i Carić je svoje prisno poznavanje mora i života na njemu, svoju prisnu povezanost s ljudima na njegovim obalama i njegovim pučinama, svoje zanose pred njegovim prizorima i njegovim dramama, prosuo u svom djelu ispremiješano $\mathrm{i}$ isprepleteno $s$ poučnim umecima o golim praktičkim faktima. ${ }^{24}$

Upravo na takvu isprepletenost mislio je i Benjamin kada je govorio o „rođenim pripovedačima“ ${ }^{25} \mathrm{i}$ „istinskoj priči“. ${ }^{26}$ Takvi se pripovedači zanimaju i za praktične delatnosti, a svojim čitaocima dele najrazličitije savete, pa njihove priče „otvoreno ili prerušeno“ donose u sebi ono u čemu su od koristi. Jednom rečju - mudrost, koja u vreme opadanja pripovesti nestaje. ${ }^{27}$ Kao primer rođenog pripovedača Benjamin i jeste istakao baš pomorca, „kapetana O..." u eseju / priči Maramica (1932), u kojem se začinju i sve postavke razvijene u Pripovedaču. U Maramici, uostalom, Benjamin definiše i ulogu amblema u priči.

Vratimo li se periodičarskom motivu koji je odveo ka dalekosežnijim problemima Desničine pripovedačke poetike, ali i teorije pripovedanja uopšte, moglo bi se sažeto reći sledeće: motiv kalendara-stogodnjaka predstavlja, dakle, amblem koji učestvuje u karakterizaciji lika odnosno likova, zatim preko njih u oblikovanju semantičke opozicije selo - grad i odgovarajućih koncepcija vremena i smrti, a preko relativizacije datog binarizma i u oblikovanju Desničinog integralizujućeg i ambivalentnog pripovedača.

\section{3 .}

U pripoveci Zlatni rudnik ${ }^{28}$ Desnica je pomoću motiva dnevnih novina, Večernjeg lista, oblikovao dve semanteme iz domena tematsko-motivskog kompleksa smrti: jednu, o smrti kao biološkom usudu ljudske vrste i, drugu, o njenom društvenom aspektu - o prolaznosti

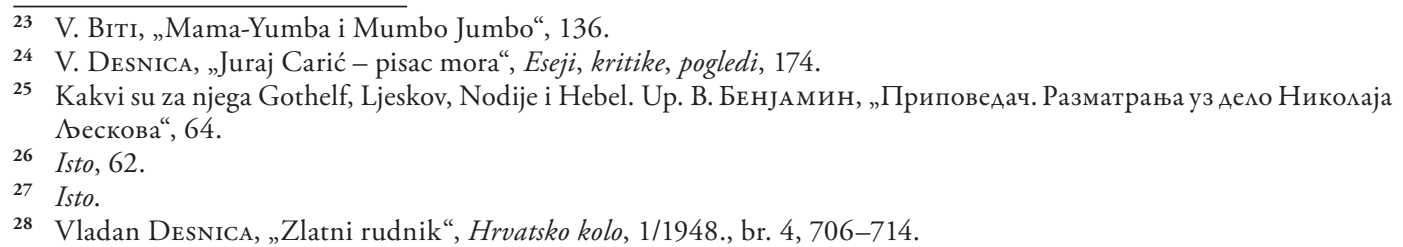


umetničke slave. Te dve semanteme Desnica je objedinio učinivši ih delom životne priče istog junaka. I „uvijajući“ ih u istu novinsku hartiju. Uz to, kombinujući ove motive i sugestivne pripovedačke komentare na odgovarajućim mestima narativnog toka Desnica je stvorio efekat samog vremenskog proticanja.

Zlatni rudnik priča je o Joži Grabeku, koji od siromašnog šegrta u jednoj pekari postaje poznati operski pevač u svome gradu (Zagrebu). Slučajno otkriće profesora, koji u prolazu čuje izuzetni Jožin glas, i nagli prelazak iz anonimnosti u, najpre, gradsko čudo a ubrzo i u opersku zvezdu, proizvode onu vrstu događajnosti koja stvara iluziju zaustavljanja vremena. Pripovedač kaže:

Neosjetno je prolazilo vrijeme (kako se to u filmu prikazuje spontanim odlijetanjem listića $s$ kalendara) - deset godina - i prvi, neslužbeni jubilej došao je kao od šale. ${ }^{29}$

Ovaj pripovedački komentar s fokalizacijom na svest junaka - naročito blizina reči neosjetno i značenje polurečenice u zagradi (spontanost i brzina) - opisuje paradoks subjektivnog doživljaja vremena u danima uspona i slave. Vreme stoji i u isto vreme brzo protiče. Kada prođe vreme stalnog uspinjanja a nastupi vreme karijerne stabilnosti, javlja se isti paradoks: vreme protiče tromo, a opet brzo prođe čitava dekada. Pripovedač pozivanje na stereotipnu filmsku sliku ovog puta izvlači iz zagrada. „Ponovo odlijetanje listića s kalendara", signalizuje on ukratko, i objašnjava:

U jednoličnom slijedu jednakih dana, Joža je išao neprimjetno i prema drugom, dvadesetipetogodišnjem jubileju, a još se nije dogodilo ništa od onog čudesnog, neodređeno izvanrednog što čovjek, htio ne htio, do nekih godina uvijek iščekuje. ${ }^{30}$

U tom trenutku Desnica uvodi motiv Večernjeg lista, i to tako kao da je u pripovedanju on već bio pomenut: „A Večernji list će svejednako pisati 'naš omiljeni Joža Grabek' a već nikad više 'naš proslavljeni Joža Grabek'."31 Ova je pripovedačeva rečenica data iz perspektive glavnog junaka, ali u njoj je iskazano i Desničino zapažanje o dnevnom novinarstvu kao direktnom izrazu dominantnog javnog mnjenja. Kroz osetljivo reagovanje junaka na „sitnu“ promenu u jednoj reči, Desnica se zapravo predstavlja kao kritički analitičar medijskog diskursa: implicitna značenja medijskog govora sadrže onu pravu i, što je još važnije, društveno delotvornu poruku. Onu koju autor / novinar / mnjenje / javnost ne želi eksplicitno da izrazi, a koja bi u ovom slučaju glasila: vreme Jožine slave već je prošlo.

Sliku prolaznosti Desnica je, međutim, proširio na većinu likova ove pripovetke. Ona je posebno ubedljivo prikazana preko ženskih likova: najpre, u grotesknoj slici Jožine koleginice, koja, već prestarela, igra ulogu Madam Baterflaj, zatim na liku / licu Jožine supruge, koja propada zbog siromaštva i, na kraju, kroz nezadovoljstvo i isfrustriranost Jožine kćeri:

Zdenka postaje čudna, ćudljiva, vječito se gloži s materom; zbog najmanje sitnice padne u vatru ili brizne u grčevit plač. U toku godine izmakle su joj dvije prilike za udaju, i sad

\footnotetext{
Isto, 707.

30 Isto, 708.

31 Isto.
} 
je u nju umilila nesigurnost. Malo pomalo miri se s tim da se uposli kao daktilografkinja. Ali onda se odjenom prene, pobuni se: poplaši je duga, siva perspektiva koja se time otvara pred njom; osjeća da bi to značilo odreku, kraj... Pa opet premišlja, skanjiva, odlaže... Neočekivano - obično to biva podveče - uđe u nju i uznemiri joj srce panično osjećanje vremena: čisto osjeća kako ono otiče nezaustavljivo, kako joj izmiče između prsta kao pijesak... ${ }^{32}$

I upravo u tome opisu ekspliciran je čulni doživljaj koji pripovedač postupno nastoji da izazove kod čitalaca - panično osé́anje vremena, u vidu lupanja srca, i njegov taktilni ekvivalent, osipanje peska kroz prste. U ovome posebnu ulogu igra jedan dogadaj smrti koji je deo nezaustavljivog toka Jožine prolaznosti, ali stoji i sam za sebe - kao izdvojena slika. Jožina supruga, naime, u trenutku Jožinog zenita / propadanja donosi na svet mrtvorođenče. Zatičući ih, Joža „razmisli malo pa dohvati s ormara dva tri stara broja Večernjeg lista, uze iz lavora klimavo tjelešce i zamota ga u novine; u kuhinji iza vrata dohvati kotlju kojom su okopavali povrće, i iziđe u vrt “. ${ }^{33}$ Večernji list Desnica je, dakle, vrlo promišljeno upotrebio kao znak smrtnosti i prolaznosti. U ovom slučaju, groteskna slika - obmotavanje mrtvorođenčeta dnevnim novinama - potencira ideju o upisanosti smrti u životni (pret)početak, odnosno o smrti kao biološkom usudu.

Kako bi (pr)oticanje vremena junakove slave dobilo na ubrzanju, pripovedač u radnju uvodi policijski uviđaj, zbog sumnje da je reč o čedomorstvu. Joža je tako proveo jedno veče na ispitivanju u policijskoj stanici, posle čega mu se, nakon što biva pušten i oslobođen sumnji, ,jače nego ikada ranije“, učini da je svet mesto besmislenih i uzaludnih događaja i sudbina. Taj doživljaj Desnica ponovo pojačava periodičarskim amblemom:

Šćućureni pod kandelabrima, slični pokislim ćurkama, prodavači novina izvikivali su svježi broj Večernjeg lista. Snagom navike, Joža se uputi prema njima s dvodinarkom među prstima. Ali na pola puta zastade - učini mu se da zna već unaprijed što može da u njima piše: da je novopostavljeni poslanik kakve Venezuele predao svoje akreditive ili da se u općini Sv. Martin opet pojavila svinjska kuga.

On odmahnu rukom, spremi dvodinarku u džep, i krenu prema kući. ${ }^{34}$

U pominjanom Benjaminovom eseju nalaze se pasusi direktno prizvani ovim Desničinim odlomkom. Kada eksplicira kako štampani mediji (posebno dnevna štampa) i informacije deluju na štetu pripovedanja, Benjamin to slikovito objašnjava:

Vilmesan, osnivač lista Figaro, okarakterisao je suštinu informacije glasovitom formulom: „Mojim čitaocima“, obično je govorio, „važniji je požar na tavanu u Latinskom kvartu nego neka revolucija u Madridu. ${ }^{\text {"35 }}$

Benjamin time dokazuje kako se u vreme dominacije periodične štampe „manje obraća pažnja na vest što dolazi iz daleka nego na informaciju koja nudi oslonac da se obavestimo o onome što nam je najbliže“, što sve zajedno govori priča „rado otvorena prema čudesnom“,

\footnotetext{
32 Isto, 710.

33 Isto, 711.

34 Isto, 715.

35 В. БенЈАмин, „Приповедач. Разматрања уз дело Николаја Бескова“, 69.
} 
a „za informaciju je neophodno da zvuči plauzibilno“, pa se na taj način pokazuje kao nepomirljiva sa duhom priče. ${ }^{36}$

Desničini junaci u trenucima simboličkog ili stvarnog umiranja, kada osete sopstvenu prolaznost, ne pridaju više važnost ni bliskim ni dalekim događajima, ni običnim ni revolucionarnim vestima, jer za njih sve postaje jedno isto. I to je u Desničinoj pripovednoj semantologiji znak da je vreme stalo, odnosno da je junakovo vreme isteklo.

\section{4 .}

Oblikovanje političke biografije lika uvođenjem novin(ar)skog motiva prisutno je i u pripoveci Konac dana, čiji je glavni junak opštinski prvak Mile Srdarević-Prkut. „U malim dalmatinskim gradovima" Desnica je, kako svedoči u pismu Aleksandru Tišmi od 23. marta 1952. godine, susreo „čitav niz ljudi na kalup dra Mile Srdarevića-Prkuta“ i „ta je pojava nesumnjivo tipična za dato vrijeme i sredinu“, zbog čega je smatrao smislenim „literarno fiksirati taj tip čovjeka i ocrtati turobnu životnu krivulju izgubljene egzistencije“. ${ }^{37} \mathrm{U}$ prezimenu Srdarević prisutna je i aluzija na najbliže članove Desničine porodice, čiji se biografski momenti mogu prepoznati i u „životnoj krivulji“ junaka. Na planu obima pripovetke, najveći deo te krivulje posvećen je pak simboličkoj, odnosno političkoj smrti glavnog lika, samom procesu političkog umiranja, i njegovog (ne)mirenja sa tom činjenicom.

Mile Srdarević-Prkut, nekadašnji bečki student prava, nekoliko godina pred Prvi svetski rat osniva list Nova zora, paralelno sa sopstvenom političkom partijom. Međutim, ovaj list - naziva karakterističnog za glasila kakva je pokretala južnoslovenska omladina u Austrougarskoj monarhiji, usmerena protiv monarhije i opredeljena za jugoslovensko ujedinjenje nije samo znak konkretnog političkog profila junaka. Naime, budući da Desnica prikazuje kako date ideje i njihovi nosioci vremenom gube prvobitni, pa i svaki društveni značaj, (p) ostajući tek olupine na suncu, dalja upotreba istog novinskog motiva u pripoveci u tom je znaku. Čitalac će u daljem toku razvoja „radnje“, uveliko posle rata, kada Mile Prkut izgubi i funkciju predsednika opštine, zateći ovog junaka kako sa setom prelistava stare ukoričene godišnjake Nove zore, da bi ga na kraju gledao suočenog sa činjenicom da nijedan list više ne želi da objavi bilo kakav njegov članak:

Zatim je poslao članak jednom prestoničkom listu s poduljim pismom u kome ih je podsjećao na svoju političku prošlost, koje se oni sigurno sjećaju, i iscrpno im naslikao prilike na općini. Odgovorili su mu učtivo upućujući ga na provincijski dnevnik, kod čijih će čitalaca stvar nesumnjivo naići na kudikamo veći interes, jer se radi o mjesnim ljudima i prilikama. Poslušao je taj savjet, no provincijski dnevnik nije mu ni odgovorio na pismo. ${ }^{38}$

Desnica je pažljivo gradio i ritmičke efekte ove pripovetke. Motiv časopisa Nova zora javlja se u tri ključna trenutka: na početku junakovog političkog prodora (osnivanje stranke

\footnotetext{
Isto.

37 „Vladan Desnica o svom književnom radu i pogledima na književno stvaralaštvo“, Eseji, kritike, pogledi, 247.

38 Владан АЕсницА, „Конац дана“, Brazda, 4/1951., br. 7-8, 516.
} 
i časopisa), ${ }^{39} \mathrm{u}$ trenutku najvišeg uspona (propagandna delatnost Nove zore u balkanskim ratovima $)^{40}$ i u trenucima političkog odumiranja, kada se Nova zora više ne objavljuje već je junak čita ukoričenu i samim tim - arhiviranu: „Listao je godišnjake 'Nove zore' i trljao prozeble ruke, jer je u toj daščanoj izbi nerado ložio malu gvozdenu peć.“41

Ovako naglašenu, pomoću amblema Nove zore, Desnica je u ovoj razuđenoj pripoveci ideju političke smrti i prolaznosti iskazao na svim nivoima pripovedanja: kroz doživljeni govor junaka, karakterizacije drugih likova i njihove reakcije, razvijanje lokalnog političkog zapleta, ali i filozofsko-gnomske iskaze. Pripovetka, naravno, intertekstualno komunicira sa dve ranije priče iste tematike. $U$ danima po oslobođenju i osnivanju Kraljevine, junaka, naime, progoni „neki nejasni osjećaj da još mnogošta ima da se učini, i to jako hitna i važna; ali što - toga se nije pravo prisjećao“. 42 Kao i Joža Grabek u pripoveci Zlatni rudnik, tako i ovaj junak očekuje nešto, nešto izuzetno, važno i veliko, ali to veliko delo ili događaj po pravilu izostaju. Kao i Joža Grabek, i Mile Srdarević-Prkut nije uspeo da predvidi početak svog karijernog kraja, blizinu društvene smrti. Isto tako, ponavlja se ideja o postojanju jedne paradoksalne životne tačke, u kojoj zenit uspeha znači početak njegovog kraja, odnosno, još preciznije, trenutak koji se subjektivno doživljava kao novi životni početak, objektivno znači simboličku smrt. Ta je ideja najsažetije i najopštije izražena u rečenici: „I sad kad je računao da je napokon dočekao svoje doba, počeo je shvaćati da je njegovo doba već prošlo. “43 Ona je ubrzo i varirana kroz konkretniju sliku:

I u jedno sivo nedjeljno popodne kad mu je prijetnja kiše osujetila šetnju i zadržala ga u sobi, Mili se prvi put prokrala glavom pomisao da je čas kad je doživio ostvarenje svojih snova iz mladosti bio pravi čas da umre. ${ }^{44}$

Uopšte, u ovoj je pripoveci Desnica na mnogo načina varirao iste ideje i slike, postižući i tim postupkom utisak ponavljanja, ritmizirajući samo pripovedanje, kako bi ostvario efekat vremenskog toka i osećaj postupnog umiranja. Pored periodike, u Koncu dana uvodi se kao motiv još jedan komunikacijski format / žanr koji ima istu funkciju - da otkucava časove života, i da daje ritam životu odnosno samoj njegovoj prolaznosti. Reč je o slanju čestitki za rođendane, imendane i praznike, čega se junak doseti kao spasonosne aktivnosti, ,porađajući mu prijatnu iluziju da je još živ u pamćenju ljudi““活 U pomenutom pismu Aleksandru Tišmi Desnica je eksplicirao upravo ove aspekte svoje poetike: iznoseći opštiju

39 „I doista, Mile se sasvim bacio na ono drugo polje. Pokrenuo je svoj list, 'Novu zoru', i osnovao stranku u koju je povukao mahom seljake iz mjesta i okolnih sela. Ta je stranka bila gotovo Milina lična svojina; prostorije su joj se nalazile u njegovoj kući, on je snosio njene troškove i finansirao njene pothvate.“ В. АЕсницА, „Конац Аана“, 506.

40 „Početak Balkanskog rata zatekao je Milu u Beogradu gdje je bio poveo grupu uglednijih seljaka iz stranke, a po povratku razvio je u 'Novoj zori’ živu propagandu za saveznike. (Protivnici su se zlurado podsmijevali govoreći da Balkanskom savezu treba pribrojiti još jednu silu: Milinu općinu.) Sve to nije izmaklo pažnji vlasti, pa čim je buknuo Svjetski rat, Mile je uhapšen i s drugim viđenijim dalmatinskim ljudima interniran, a njegova općina raspuštena upravo u jeku priprema za proslavu Milina dvadesetgodišnjeg jubileja. A kad je rat svršio, Mile je uspostavljen u časti i odlikovan Svetim Savom II stepena." Isto, 508.

41 Isto, 513.

42 Isto, 508.

43 Isto.

44 Isto, 509.

45 Isto, 515. 
tezu da tema, „materija“, određuje formu pripovetke, otkrio je da pod formom podrazumeva specifično i ritam („Ona diktira tempo, ritam, dramatičnost, način pristupanja...“). ${ }^{46}$

Uz teme političke smrti i prolaznosti političke slave, koje su u prvom planu, Desnica je u pozadini priče prikazao i smrt imperije. Pošto pripovetka jasno sugeriše kako se tek zahvaljujući tome što jedni umiru a drugi se rađaju, teme osnivanja jugoslovenske kraljevine ili „rađanja“ $i$ uspona novih političkih generacija takođe se mogu shvatiti kao motivi unutar istog tematskog kompleksa. Odnosno, u slici uspona novih lokalnih moćnika i nove države čitaoci već vide i njihovu (političku) smrt.

Fiktivni list Glasnik udruženja poštanskih službenika pojavljuje se u pripoveci Oproštaj. U ovoj kratkoj priči, koja opisuje postupno umiranje junaka Antuna, „petnaestdnevni“ esnafski glasnik poprima dvostruko značenje: kao i u drugim pripovetkama, jedan je od znakova prolaznosti života, ali je i „sredstvo“ odbrojavanja poslednjih junakovih dana. Kako je ovaj časopis pomenut samo jednom u pripoveci, i nije eksplicitno naznačen duži protok vremena u vezi sa njim (kao npr. osnivanje i prvi brojevi Nove zore, i njihov kasniji arhivski, ukoričeni oblik; ili slike Večernjeg lista koje ocrtavaju „krivu“ od mladosti do starosti junaka), pitanje je pojedinačnog čitalačkog doživljaja da li će junakovo umiranje, ukoliko ga uopšte vremenski precizira, videti kao poslednjih petnaest dana njegovog života ili će se pak činiti da je reč o višemesečnom procesu u kojem se vidljivije promene fizičkih i mentalnih sposobnosti odvijaju na dvonedeljnom nivou. Zbog uverljivog opisa fizičkog onemoćavanja i „obesvešćivanja“, ${ }^{47}$ čitaoci su navedeni i na ovakve biomedicinske pretpostavke, ali je upravo izabranim postupkom - da pripovedač samo jednom pomene polumesečni Glasnik - Desnica postigao efekat gubljenja osé́aja za vreme i proticanje vremena.

Kao dodatni ritmički signali, koje pripovedač „uzgredno“ nudi čitaocima, tu su podaci o dolascima služavke Ane, na početku priče (ona dvaput nedeljno briše prašinu, odnosno dolazi svakog dana u posetu), i jedan od poslednjih deskriptivnih pasusa. Na samom kraju priče, naime, kao završni akord u postizanju ritmičkog efekta u opisu umiranja junaka, pripovedač je prizvao jedan melodijski doživljaj: poslednji zvuci koje junak čuje jesu zvuci motorne testere kojom komšija seče drva. Pripovedač ih predstavlja kao zvuke koji se javljaju u pravilnom ritmu, jer „iz ujednačene ulične vreve isplivavaju u jednakim razmacima reski rzaji zupčastog koluta kao delfinove peraje s pramom srebrne pjene iz mora“" ${ }^{4} 8$

U ovoj pripoveci Vladan Desnica se potpuno približio samom iskustvu umiranja. Središnja slika umiranja, data istovremeno i spolja i iznutra, kroz junakovu svest odnosno obesvešćivanje, uokvirena je drugim slikama umiranja i smrti. U jednoj od Desničinih najkraćih priča sve zapravo vrvi od mrtvih i umirućih likova: druga Antunova supruga, od njega mnogo mlađa, umire iznenada, u trenutku kada je i njegovo umiranje počelo, pa joj

\footnotetext{
Isto, 246.

47 Videti tekst Bojana Đorđevića u ovom zborniku.

48 Вцадан АЕсницА, „Опроштај“, Аemonuc Mamuцe срnске, 127/1951., br. 4, knj. 368, 299. Kurziv S. B.
} 
Antun zato ne može otići ni na sahranu; u danima umiranja Antun se seća prerano umrle prve žene i prerano umrlog sina (dečak se sa sedam godina polio kipućom vodom); a pod vrata ubačena mu je „osmrtnica“ nepoznatog čoveka. Ove raznovrsne smrti (prirodne ili nesrećnim slučajem izazvane, očekivane ili neočekivane), smeštene u različite tačke „subjektivnog“ i „objektivnog“ fabulativnog (vremenskog) niza, oblikuju svojevrsnu koordinatnu osu motivskog kompleksa smrti, u koju je smeštena i glavna tema. Ovim je postupkom Desnica pojačao sugestivnost osnovne teme, ocrtao joj ram koji će je učiniti vidljivijom.

Amblemska upotreba časopisa, kao upadljivog detalja na toj slici, ogleda se ne samo u uspostavljanju ritma (umiranja i pripovedanja), već i produbljivanju saznajne perspektive - upravo u opisu časopisa, kroz omalovažavanje vesti i dnevnih događaja, pripovedač favorizuje prolaznost ljudskog života. On, naime, kaže:

Od novina je primao jedino petnaestdnevni Glasnik udruženja poštanskih službenika koji je donosio uglavnom samo „stručne i staleške vijesti“. Tek u jednom stupcu na četvrtoj strani bila je rubrika „Događaji u svijetu kroz petnaest dana“. Ali je tu svim vijestima dat neki statistički vid; nizovi riječi bivali su isprekidani mnogoznamenkastim brojevima preko kojih klizne pogled ne zadržavajući se. Nijedna vijest iz te rubrike nije bila kadra da poprimi vid slike: područje na kome hara kuga u Indiji proširilo se za... (cifra s mnogo ništica) kv. kilometara; ili „u Sjedinjenim Državama broj neuposlenih porastao je na... (opet cifra s ništicama)", i tome slično. Čak i vijest, da je u jednoj južnoameričkoj državi izbila revolucija i da je, nakon šest dana ogorčenih borbi, došao na vlast vođa pobunjenika general Florencio Garigo, bila je suha kao upis u maticu, dokraja doigrana i već bačena iza leđa. ${ }^{49}$

Ovaj odlomak kao da je pisan u dijalogu sa Benjaminom. Pored asocijacije na već citirani odlomak o lokalnim i globalnim vestima, ovde je prizvano mesto na kojem Benjamin uspešnim pripovedanjem definiše ono što pripovedni događaj smešta na pravo mesto u „istoriju prirode“. „U uzornom se obliku to izražava“, smatra on, „u jednoj od najlepših priča koje nam je podario nenadmašni Johan Peter Hebel“ ${ }^{50}$ Reč je o priči „Nenadani ponovni susreti“, štampanoj u Kovčežiću s blagom rajnskog kućnog prijatelja. Benjamin to posebno ne napominje, ali je ovde važno istaći da je Kovčežić zapravo kalendar-almanah, blizak imaginarnom „kalendaru-stogodnjaku“ iz Desničine prve priče, Srbsko-dalmatinskom magazinu koji mu je predložak, ali i modernom almanahu u kom je Desnica priču objavio. I Hebel je, kao i Desnica, urednik kalendarske publikacije u kojoj objavljuje svoju priču, a te se priče u nemačkoj tradiciji i nazivaju - kalendarskim.

Opis postupanja rođenih pripovedača u Hebelovoj priči i sličnost Desničinog postupka u Oproštaju, sličnost koja je vid ironijskog otklona, ukazuje na tradiciju kalendarskih priča iz koje je Desničino pripovedanje poteklo i od koje se jednovremeno i emancipovalo. Benjaminu omiljena Hebelova priča, prepričava on tako da ujedno i sam pripoveda,

(...) započinje veridbom mladića koji radi u rudnicima Faluna. Veče uoči venčanja, u dubini rudarskog okna, iznenadi ga uobičajena rudarska smrt. Njegova verenica ostala mu je verna i posle smrti, a živela je dovoljno dugo da, kad su iz napuštenog okna na svetlo dana izneli leš koji se zasićen kristalima gvozdenog sulfata bio očuvao od raspadanja, kao već

$49 \quad$ Isto, 296.

50 В. БенЈАмин, „Приповедач. Разматрања уз дело Николаја Вескова“, 79. 
prastara bakica ona prepozna svog verenika. Posle tog ponovnog susreta i nju prizove smrt. Kad se sad Hebel, tokom pričanja, našao pred neophodnošću da dočara dugi niz godina, učinio je to ovim rečenicama: „U međuvremenu je u Portugalu zemljotres razorio grad Lisabon, i završio se sedmogodišnji rat, i umro je car Franja Prvi. (...) Napoleon je osvojio Prusku, Englezi su bombardovali Kopenhagen, a seljaci su sejali i žnjeli. Mlinar je mleo i kovači su kovali i rudari su kopajući tražili minerale u svojoj podzemnoj radnji. A kad su rudari u Falunu 1809. godine..." ${ }^{\text {.51 }}$

Benjamin će u karakterističnom sugestivnom tonu istaći da „nikad nijedan pripovedač nije dublje smestio svoj izveštaj u istoriju prirode nego što je to učinio Hebel u svojoj hronologiji “ 52 Ono što, pak, teoretičar traži od čitalaca jeste da primete kako se u takvom pripovedanju pozicionira smrt: u pravilnom ritmu jednog pravilnog ciklusa. Desničin pripovedač u Oproštaju smešta svoj izveštaj u istoriju prirode, ali u isto vreme se i ironijski ograđuje od toga postupka, budući da događaje prikazuje kao vesti, a vesti onako kako ih u trenutku umiranja vidi njegov junak - kao beznačajne. Novinske vesti, nisu, međutim, predstavljene kao beznačajne samo zato da bi se time ubedljivo opisao junak koji umire, već zato da bi se saopštilo kako su one beznačajne i za samog pripovedača. U Hebelovoj pripoveci, veliki i mali događaji još uvek su imali vrednost, kao donekle i u Desničinoj prvoj pripoveci, dok su ovde predstavljeni kao informacije, pa ni smrt nije moguće smestiti u neku jasnu istoriju prirode. Kao što Vladimir Biti primećuje povodom romana Proljeća Ivana Galeba, oslanjajući se na ovaj segment Benjaminovog eseja:

U iščašenom vremenu smrt više ne pripada nepomućenoj „povijesti prirode“ gdje „dolazi u tolikom pravilnom turnusu kao da je to kosac u procesijama koje u podne obilaze oko crkvenog sata". 53

U ovom se odlomku jasno razlikuju nivoi rascepa između dve vrste trajanja. Naime, sam svet esnafskih časopisa (koji donose pretežno stručne i staleške vesti) jeste svet bez promena, bez događaja, svet pukog trajanja, u kojem nema individualnih postignuća; zato, i kada u taj svet prodre događaj, u obliku vesti, dodeli mu se „statistički vid“ i on utone u uspostavljenu bezličnost („Nijedna vijest iz te rubrike nije bila kadra da poprimi vid slike“). ${ }^{54}$ Ako je tako i inače u svetu poštanskih službenika (pa samim tim i njihovih glasila), još je veći otpor prema Događaju u trenutku njihovog silaska sa pozornice sveta. Drugi deo opisa časopisa, koji govori o konkretnoj vesti, ne pripada više samo instanci pripovedača, već je prelomljen i kroz perspektivu junaka: umirućem Antunu, kojem ništa više nije važno, vest o revolucionarnoj promeni izgleda beznačajno, beznačajnije nego što bi je mogao predstaviti i njegov staleški časopis. 


\section{6.}

Analiza četiri pripovetke Vladana Desnice pokazala je kako je periodična štampa upotrebljena kao motiv koji amblematski potkrepljuje opštiji motiv odnosno temu umiranja, smrti i ljudske prolaznosti. Amblemski potencijal periodike leži u analogiji između datih motiva: i jedno i drugo počivaju na vremenitosti, na određenosti vremenom, što je Vladan Desnica umetnički i saznajno uspešno iskoristio u ovim pripovetkama. Amblemska je upotreba motiva periodične štampe doprinela uspostavljanju ritma, kako (u slici) umiranja tako i ritma samog pripovedanja. Analiza pripovedaka nastojala je, dakle, da ukaže da specifična umetnička vrednost Desničine proze ne leži samo u ubedljivom prikazivanju aspekata smrtnosti i iskazivanju ideja u tome domenu, već i u proizvođenju određenog čulnog doživljaja. Pomoću datih slika i semantema, u sveukupnom dejstvu pripovedačkih postupaka, u čitalačkom se doživljaju, naime, ostvaruju i efekti samog proticanja vremena, odnosno samog osećaja prolaznosti.

Raspon i hronologija izabranih pripovedaka, od Jandrije Kutlače do Oproštaja, ujedno pokazuje i kako se odvijala svojevrsna evolucija pripovedača u Desničinoj prozi. U objašnjenju date evolucije kao adekvatan teorijski oslonac poslužila je teorija epskih oblika Valtera Benjamina, a posebno njegov esej Pripovedač, pisan u isto vreme kada i Desničina prva pripovetka. Zanimljivo je, najpre, da se Benjaminova teorijska imaginacija i eksplikacija idealnog pripovedača podudara sa književno realizovanom pripovednom instancom u $\check{Z} i$ votnoj stazi Jandrije Kutlače: obe u sebi spajaju (saznajno-psihološke) perspektive ratara i nomada. Drugo važno podudaranje jeste povlašćenost teme smrti. Oblikovanje ambivalentnog i integralizujućeg pripovedača u Desničinom proznom prvencu rezultira i relativizujućim odnosom prema konačnosti smrti jer uključuje ciklični model vremena. S tim u skladu, i završetak pripovetke, u kojem se iščekuje smrt, nosi optimistički prizvuk, posebno u izvornoj verziji iz 1935. godine. Nije nimalo čudno što će u narednim verzijama optimističnost završetka biti prigušena, budući da, kako tri sledeće odabrane pripovetke pokazuju, Desnica sve više povlašćuje temu smrti, a instanca pripovedača sve je manje epistemološki ambivalentna - bliža je konceptu progresivnog toka vremena, a samim tim i neumitnosti smrti, odnosno tragičnom viđenju prolaznosti.

Ukoliko se posle prve pripovetke udaljio od usmenog konteksta pripovedanja (za koji ga je, pored stila, vezivao sam časopisni kontekst - objavljivanje pripovetke u jednom almanahu), Desnica je u naredne tri pripovetke sačuvao drugi benjaminovski pripovedački ideal, koji je pred izazovom u medijskoj eri: sposobnost prenošenja i saopštavanja (celovitosti) iskustva odnosno mudrosti, uprkos dominaciji (fragmentarnih) informacija. Desnica je pomenuti ideal realizovao zapravo kroz narativni postupak u kojem periodična štampa postaje amblem, upečatljivo ali podređeno sredstvo ukupnog narativnog sklopa i značenja. Posle primene datog postupka u pripovetkama Zlatni rudnik i Konac dana, u pripoveci Oproštaj, koja hronološki dolazi na kraju, Desnica ga je doveo do njegovih krajnjih konsekvenci: pripovedač je temu prolaznosti ljudskog života favorizovao kroz potpuno omalovažavenje dnevnih događaja i medijskih vesti. 


\section{$\cos$}

\section{Izvori i literatura}

\section{Izvori}

Vladan DesnicA, „Jedan zakašnjeli prilog diskusiji o tipičnome“, Eseji, kritike, pogledi (= Sabrana djela Vladana Desnice, knj. IV), Zagreb 1975., 71-91.

Vladan Desnica, „Juraj Carić - pisac mora“, Eseji, kritike, pogledi (= Sabrana djela Vladana Desnice, knj. IV), Zagreb 1975., 173-177.

Вцадан АЕсницА, „Конац дана“, Brazda, 4/1951., br. 7-8, 505-524.

Vladan Desnica, „Ličnost i prosede“, Eseji, kritike, pogledi (= Sabrana djela Vladana Desnice, knj. IV), Zagreb 1975., 113-116.

Владан АЕсницА, „Опроштај“, Аетопис Mатице срnске, 127/1951., br. 4, knj. 368, 295-299.

Vladan DesnicA, „Zlatni rudnik“, Hrvatsko kolo, 1/1948., br. 4, 706-714.

Владан АЕсницА, „Животна стаза Јандрије Кутлаче (скица за роман)“, Магазин Сјеверне Аалмачије, 2/1935., 155-173.

Vladan Desnica, „Životna staza Jandrije Kutlače“, Pripovijetke (= Sabrana djela Vladana Desnice, knj. III), Zagreb 1974., 57-88.

АЮБИТЕАЬ ПРОСВБШТЕНІЯ. СРБСКО-ААЯМАТИНСКІЙ АЯМАНАХЬ ЗА АБТО 1836. Издао га на свет Теодор Петрановић, обои права доктор. У Карлштадту, печатано у Типографији Иоана Н. Претнера.

„Vladan Desnica o svom književnom radu i pogledima na književno stvaralaštvo“, Eseji, kritike, pogledi (= Sabrana djela Vladana Desnice, knj. IV), 246-253.

\section{Literatura}

Stanislava BARAĆ, „Implicitni čitalac Magazina Sjeverne Dalmacije: pokušaj rekonstrukcije“, Vladan Desnica i Split 1920. - 1945. Zbornik radova sa znanstvenog skupa Desničini susreti 2014. (ur. Drago Roksandić i Ivana Cvijović Javorina), Zagreb 2015., 157-180.

Валтер Бенјамин, „Приповедач. Разматрања уз дело Николаја Бескова“, Искуство $u$ сиромаштво, БеограА 2016., 59-103

Vladimir Bıтı, „Mama-Yumba i Mumbo Jumbo: Proljeća Ivana Galeba Vladana Desnice“, Doba svjedočenja, Zagreb 2005., 135-171.

Milomir Gavrilović, „Odlike enciklopedijskog modela proze u Proljećima Ivana Galeba Vladana Desnice i Peščaniku Danila Kiša“, Hrvatsko-srpski / srpsko-hrvatski interkulturalizam danas. Zbornik radova s medunarodnoga znanstvenog skupa Desničini susreti 2016. (ur. Drago Roksandić), Zagreb 2017., 236-248.

Davor Dukić - Goranka Šutalo, „Todesenthebung aus dem Sterbzimmer: koncepti ideologije i vlasti u recepciji Desničinih Proljeća Ivana Galeba“, Desničini susreti 2010. Zbornik radova (ur. Drago Roksandić i Ivana Cvijović Javorina), Zagreb 2011., 62-77.

Drago Roksandić, „Vladan Desnica i Magazin Sjeverne Dalmacije: književnik i (ne)moć tradicije“, Vladan Desnica i Split 1920. - 1945. Zbornik radova sa znanstvenog skupa Desničini susreti 2014. (ur. Drago Roksandić i Ivana Cvijović Javorina), Zagreb 2015., 181-234.

Zdenko ŠKreB, „Amblem“, Rečnik književnih termina, Beograd 1992., 20. 


\section{$\cos$}

\section{The MAGAZINE AS AN EMBLEM OF THE FINAL HOUR: THE INTERDEPENDENCE OF THE MOTIFS OF DEATH AND PERIODICALS IN THE WORKS OF VLADAN DESNICA}

In several of Vladan Desnica's short stories, periodicals are a motif which emblematically supports the more general motif, or rather, the theme of dying, death and transience. Desnica uses a variety of types of periodicals (the calendar/almanac, i.e. the yearbook, a magazine of politics and culture, the bimonthly newsletter, the daily newspaper) to represent the metaphysical theme and the philosophical message he wishes to convey. The purpose of this paper is to show the variety of ways in which these motifs are built into the narrative and semantic structures of the short stories and to point out the artistic innovativeness of such a procedure. Additionally, the paper aims to show how the aforementioned motifs function within the larger poetics of Vladan Desnica. They contribute to shaping the semantic opposition between the village and the city (the opposition between the rural and the urban perception of time and transience is highlighted through the motif of the hundred-year calendar in the short story Životna staza Jandrije Kutlače [The Life and Times of Jandrija Kutlača]), to depicting dying as a process (achieved by introducing the imaginary Postal Workers' Gazette in the short story Oproštaj [The Parting]) and mortality as biological destiny (the purpose of the newspaper Večernji list in the short story Zlatni rudnik [The Goldmine]), as well as expressing the idea of human transience through showing the impermanence and the deceptiveness of glory, be it political (achieved through the motif of the imaginary paper Nova Zora and other periodicals in the short story Konac dana [The end of the day]), or artistic (again by using Večernji list in The Goldmine). Set up like this, the analysis of those short stories shows that the specific artistic value of Desnica's prose lies not only in the convincing depiction of mortality and expressing ideas in that domain, but also in producing a certain sensory effect. Through the provided images and semantemes, by the effect of the totality of narrative procedures, the sense of passing time and the feeling of transience itself are created in the reader's mind. In addition to this, the example of the interdependence of the motifs of periodicals and death is indicative of the ways in which Desnica implemented an explicit poetic understanding of expressing the universal through the specific on the level of the inherent poetics: not only can the ephemeral nature of periodicals in this context be understood as something notably specific, as opposed to the universal nature of death and the awareness of transience, but these stories also show clear signs of the autobiographical, which is successfully transformed into something artistically specific, and thus universal.

Key words: Vladan Desnica, short stories, poetics, periodicals, time, transience, the specific, the universal 